\title{
Scheloribates distinctus Mihelčič, 1964 - a species of mite (Acari: Oribatida) new to fauna of Poland and new records of three rare species
}

\author{
Grzegorz GRYZIAK \\ Centre for Ecological Research PAS, Konopnickiej 1,05-092 Lomianki, Poland; e-mail: ggryziak@cbe-pan.pl
}

\begin{abstract}
A new to fauna of Poland oribatid mite species (Scheloribates distinctus) and new localities of three rare species (Protoribates pannonicus, Punctoribates ghilarovi, Oppia nitens) are recorded from old compost heap in Łomianki near Warsaw, Mazovia Region, Poland.
\end{abstract}

Key words: Scheloribates distinctus, Oppia nitens, Protoribates pannonicus, Punctoribates ghilarovi, new record, oribatid mites

\section{INTRODUCTION}

There is over 40000 named species of mites (it is estimated that there is even 1 million unnamed species) and about 11000 of described oribatid mites (Walter and Proctor 2004), with ca. 500 species occurring in Poland. It is almost half of European oribatid species (Olszanowski et al. 1996). Recognition of oribatid mites' distribution is still unsatisfied as well (Niedbała 2004).

Windrows of compost are hot-spots of soil biodiversity in local scale and can be very promising in faunistic research (Rozkošný 1982, Ødegaard and Tømmerås 2000). High richness of species and high abundance of individuals, are both much larger in compost heaps than in surrounding soil (Walter and Proctor 2004). Thereby probability of discovery of new or rare species is relatively high there.

\section{METHODS}

Mites were extracted from sample of over 20 years old garden compost, consisted of kitchen and garden vegetable litter, in January 2004, in Łomianki near Warsaw. For extraction a Macfadyen apparatus was used (Krantz 1978). Specimens were cleared in lactic acid before determination and examined under a compound microscope using the half-covered cavity-slide method of Grandjean (Niedbała 1980). Keys to oribatid mites of Gilyarov and Krivolutskii (1975) and Weigmann (2006) were used for species identification. Sex of specimens was not determined due to objective obstacles in sex designation in oribatid mites (Niedbała 1980).

\section{RESULTS}

The following rare species was found in examined material:

\section{Scheloribates distinctus Mihelčič, 1964 (Oripodoidea: Scheloribatidae)}

Material: 1 specimen, January 2004, Łomianki near Warsaw, Mazovia. (UTM DC99) 
The species was known only from the one locality: Carinthia Region, Austria (Olszanowski et al. 1996, Niedbała 2004) where it was found in a coniferous litter of a mixed forest (Mihelčič 1964).

\section{Protoribates pannonicus Willman, 1951 (Oripodoidea: Protoribatidae)}

Material: 1 specimen, January 2004, Łomianki near Warsaw, Mazovia. (UTM DC99).

The species is known from Poland, Austria and Slovakia (Niedbała 2004). In Poland has been recorded only in Wielkopolsko-Kujawska Lowland (Olszanowki et al. 1996) and in Świętokrzyskie Mountains. It is reckoned to be a south European species (Zalewska and Rajski 1990). P. pannonicus occupies different habitats: marshes, arable lands (Franz and Beier 1948) and stone runs covered by lichens and mosses (Zalewska and Rajski 1990).

\section{Punctoribates ghilarovi Shaldybina, 1969 (Ceratozetoidea: Mycobatidae)}

Material: 1 specimen, January 2004, Łomianki near Warsaw, Mazovia. (UTM DC99).

P. ghilarovi is known only from Poland (Niedbała 2004) and was recorded in the one locality - West Beskid Mountains (Olszanowki et al. 1996). It dwells a litter of mixed forest (Skubała 1992).

\section{Oppia nitens C. L. Koch, 1836 (Oppioidea: Oppiidae)}

Material: 6 specimens, January 2004, Łomianki near Warsaw, Mazovia. (UTM DC99).

$O$. nitens is a widely distributed species known from West Palaearctic, Central-West Asia, East Nearctic and from Antarctica (Subías 2004). In Europe this species occurs in Austria, Belgium, Great Britain, Greece, Italy, Poland, Portugal, Spain and Ukraine (Niedbała 2004). It has been recorded only in a few regions of Poland: Pomerania Lakeland (Kaczmarek 1977), Wielkopolsko-Kujawska Lowland (Kiełczewski and Seniczak 1971, Seniczak 1975, Seniczak and Stefaniak 1978) and Lower Silesia (Frenzel 1936). O. nitens, myrmecophilic species, was found in substrates with high contents of dead organic matter, like compost (Weigmann 2006).

The faunistic knowledge of the analyzed species is sparse. Also ecological data are insufficient. However, it was confirmed, that all these species are dwellers of habitats with higher contents of dead organic matter (i.e. marshes, litter) and O. nitens even prefer those habitats (Weigmann 2006). It remains unresolved how these species got into compost: by natural dispersion or by artificial introduction with wastes.

\section{ACKNOWLEDGEMENTS}

I wish to express my sincere thanks to Dr Z. Olszanowski and Prof. W. Niedbała (Poznań, Poland) for their extremely helpful lesson and to anonymous reviewers for critical remarks on the manuscript.

\section{REFERENCES}

Franz H., BeIER M. 1948. Zur Kenntnis der Bodenfauna in pannonischen Klimagebiet Österreichs. II Die Arthropoden. Annalen des Naturhistorischen Museums in Wien 56: 440-549.

FRENZEL G. 1936. Untersuchungen über die Tierwelt des Wiesenbodens. Gustav Fischer Vlg., Jena. 130 pp.

GILYAROV M. S. \& KRIVOLUTSKIÏ D. A. (eds) 1975. Opredelitel' obitayushchikh v pochve kleshcheï (Sarcoptiformes). Nauka, Moscow. 491 pp.

KACZMAREK S. 1977. Stawonogi (Arthropoda) zasiedlające gniazda ptaków w skrzynkach lęgowych rozmieszczonych w drzewostanach leśnych. Wydawnictwo Wyższej Szkoły Pedagogicznej w Słupsku 34: 1-152.

KIEŁCZEWSKI B. \& SENICZAK S. 1971. Mechowce (Oribatei) występujące na świerku pospolitym. Prace Komisji Nauk Rolniczych i Leśnych. Poznanńskie Towarzystwo Przyjaciół Nauk 32: 45-49. 
KRANTZ G. W. 1978. A manual of acarology. Oregon State University Book Stores Inc., Corvallis, 510 pp.

MiHELČıČ F. 1964. Eine neue Art aus Kärnten. Zoologischer Anzeiger 172 (6): 678-481.

NiedbaŁA W. 1980. Mechowce - roztocze ekosystemów lądowych. Państwowe Wydawnictwo Naukowe, Warszawa, 255 pp.

NiEdBAŁA W. 2004. Fauna Europea: Mycobatidae, Oppiidae, Protoribatidae, Scheloribatidae. In: MAGOWSKI W. (ed.) 2004, Fauna Europaea: Oribatida. Fauna Europaea version 1.3; http://www.faunaeur.org

OlszanOWSKi Z., RAJSKI A. \& NiedBAŁA W. 1996. Acari: Oribatida. Catalogus faunae Poloniae XXXIV (9). 243 pp.

ØDEgAARD F. \& TØMmERÅs B. A. 2000. Compost heaps - refuges and stepping-stones for alien arthropod species in northern Europe. Diversity and Distributions 6: 45-59.

ROZKOŠNÝ R. 1982. A biosystematic study of the European Stratiomyidae (Diptera). Series Entomologica 21: 1-401.

SENICZAK S. 1975. Morphology of juvenile stages of same Oppiidae (Acarina, Oribatei). II. Pedobiologia 15: $262-275$.

SENICZAK S. \& STEFANIAK O. 1978. The microflora of alimentary canal of Oppia nitens (Acarina, Oribatei). Pedobiologia 18: 110-119.

Skubata P. 1992. Moss mites (Acari, Oribatida) new for Polish fauna. Annals of the Upper Silesian Museum (Entomology) 3: 61-66.

SuBÍAS L. S. 2004. Listado sistemático, sinonímico y biogeográfico de los ácaros oribátidos (Acariformes: Oribatida) del Mundo (excepto fósiles). Graellsia 60: 3-305.

WALter D. \& PROCTOR H. 2004. Mites: Ecology, Evolution and Behaviour. CABI Publishing, Wallingford, 322 pp.

Weigmann G. 2006. Hornmilben (Oribatida). Die Tierwelt Deutschlands, 76. Teil. Goecke \& Evers, Keltern, 520 pp.

ZALEWSKA M. \& RAJSKi A. 1990. Mechowce (Oribatida, Acarida) gołoborzy w Świętokrzyskim Parku Narodowym. Fragmenta Faunistica 25: 361-367.

\section{STRESZCZENIE}

[Scheloribates distinctus Mihelčič, 1964 - nowy dla Polski gatunek mechowca (Acari: Oribatida) oraz nowe stanowisko trzech rzadkich gatunków

Praca zawiera pierwsze doniesienie o występowaniu w Polsce Scheloribates distinctus (Acari: Oribatida). Nowe stanowisko (Łomianki koło Warszawy, UTM DC99) tego oraz trzech rzadkich w Polsce gatunków mechowców: Oppia nitens, Protoribates pannonicus i Punctoribates ghilarovi. Okazy zostały pozyskane z ponad dwudziestoletniego kompostu ogrodowego 